University of Nebraska - Lincoln

DigitalCommons@University of Nebraska - Lincoln

Publications, Agencies and Staff of the U.S.

Department of Commerce

U.S. Department of Commerce

1999

Data fusion for use of passive microwave data in operational seaice monitoring

Kim Partington

U.S. National Ice Center

Mary-Ruth Keller

U.S. National Ice Center

Paul Seymour

U.S. National Ice Center

Cheryl Bertoia

U.S. National Ice Center

Follow this and additional works at: https://digitalcommons.unl.edu/usdeptcommercepub

Part of the Environmental Sciences Commons

Partington, Kim; Keller, Mary-Ruth; Seymour, Paul; and Bertoia, Cheryl, "Data fusion for use of passive microwave data in operational sea-ice monitoring" (1999). Publications, Agencies and Staff of the U.S. Department of Commerce. 59.

https://digitalcommons.unl.edu/usdeptcommercepub/59

This Article is brought to you for free and open access by the U.S. Department of Commerce at DigitalCommons@University of Nebraska - Lincoln. It has been accepted for inclusion in Publications, Agencies and Staff of the U.S. Department of Commerce by an authorized administrator of DigitalCommons@University of Nebraska - Lincoln. 


\title{
Data fusion for use of passive microwave data in operational sea-ice monitoring
}

\author{
Kim PARTINGTON \\ Mary-Ruth KELLER \\ Paul SEYMOUR \\ Cheryl BERTOIA
}

\author{
U.S. National Ice Center \\ 4251 Suitland Road, FOB 4 \\ Washington, D.C., U.S.A. 20395-5120 \\ Voice 301-457-5314 ext. 302 Fax 301-457-5300 \\ E-mail: cbertoia@natice.noaa.gov
}

\begin{abstract}
A new SSM/I algorithm is described that is based on near real-time data fusion with portions of operational ice charts derived from RADARSAT, OLS or AVHRR data. The aim of this is to enable parts of the ice chart where there is no cloud-free imagery or SAR data to be completed using an $\mathrm{SSM} / \mathrm{I}$ algorithm that is tuned to the region and time associated with the ice chart. The algorithm is a linear combination of partial concentrations from the NASA Team and Bootstrap algorithms together with lower variance principal components of SSM/I data. The algorithm is designed for near real time use in production of operational ice charts.
\end{abstract}

\section{INTRODUCTION}

The U.S. National Ice Center (NIC), under sponsorship of the U.S. Navy, U.S. Coast Guard, and National Oceanic and Atmospheric Administration (NOAA), is tasked with mapping the ice covered oceans of the world using both remotely sensed and in situ observations. In order to achieve this mission, the NIC generates weekly ice charts that are based on data from a wide variety of sources and maintains a body of trained, expert ice analysts and forecasters. In compiling weekly ice charts, the analysts interpret RADARSAT, Defense Meteorological Satellite Program (DMSP) Operational Line-scan Sensor (OLS) data, NOAA Advanced Very High Resolution Radiometer (AVHRR) data and DMSP Special Sensor Microwave / Imager (SSM/I) ice concentration data, in decreasing order of spatial resolution. The SSM/I ice concentration data are used to "fill in" areas where higher resolution data are not available. A weakness of this procedure is that the SSM/I ice concentration data, currently available through processing with the CAL/VAL [1] and NASA Team [2] algorithms, contains errors and artifacts that preclude its use in a fully quantitative manner, as reviewed in [3]. Furthermore, the ice charts are only as good in quality as their weakest data source that, partly through fundamental sensor limitations, is the SSM/I ice concentration data.

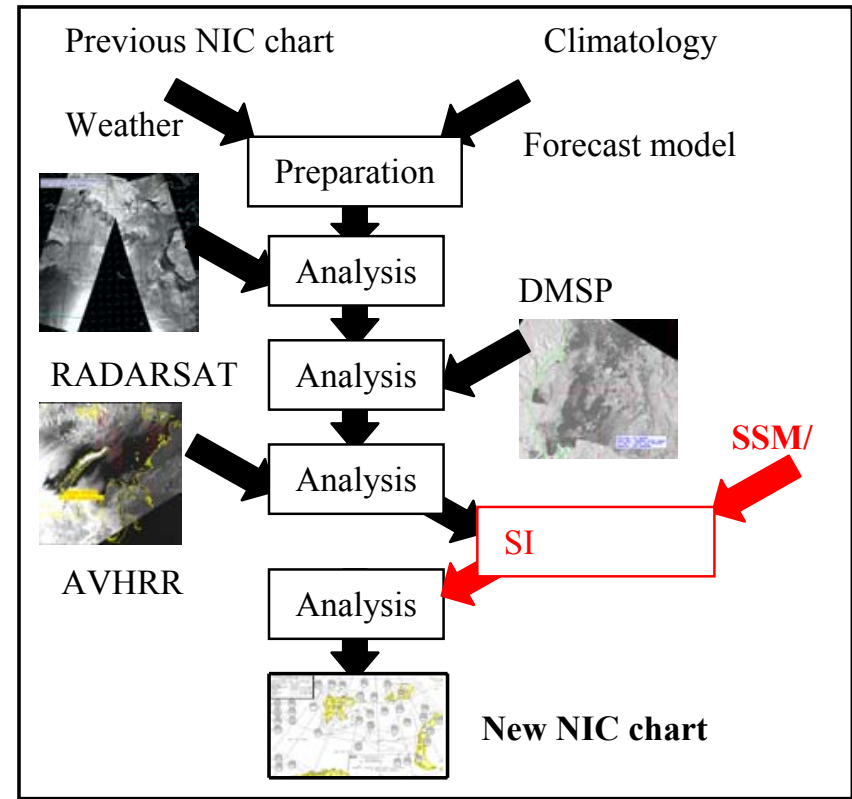

Figure 1. Context for the SSM/I Interpolation algorithm.

\section{THE SSM/I INTERPOLATION ALGORITHM}

A new data fusion algorithm, called the SSM/I Interpolation (SI) algorithm, has been designed to attempt to overcome some of the deficiencies of "conventional" SSM/I ice concentration algorithms. The context for the SI algorithm is illustrated in Figure 1. This shows how the SI algorithm ingest both an "intermediate" ice chart created from RADARSAT, OLS and AVHRR data alone, and SSM/I antenna temperatures, received in near real-time from the NOAA Center for Environmental Prediction. The ice concentration data from the ice chart are converted from vector to raster format in the projection and sampling of the $\mathrm{SSM} / \mathrm{I}$ antenna temperature data. The ice chart values are also converted from a range of ice concentrations to a single value (for example, from a coded value of " 79 " meaning $70-90 \%$ concentration, to $80 \%$ ). 


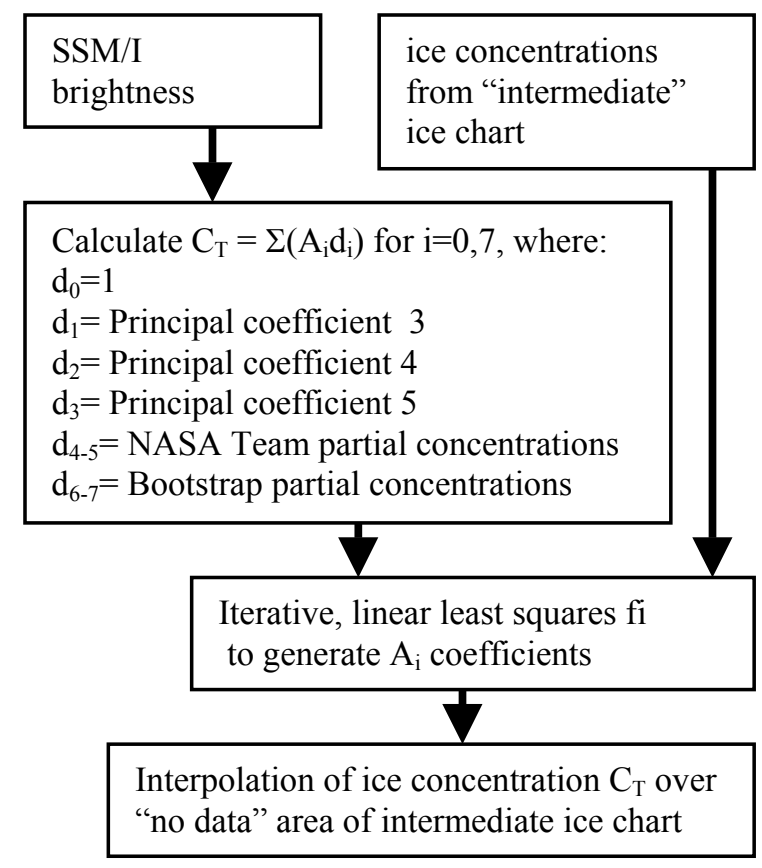

Figure 2. SSM/I Interpolation algorithm.

Figure 2 summarizes the SI algorithm. The SSM/I antenna temperatures are converted to brightness temperatures and thence into attributes. A linear model is used to specify mapping coefficients that relate the attributes calculated from the SSM/I data to ice concentrations from the "intermediate" ice chart, as shown in Figure 2. A least squares method is used to calculate the coefficients $\left(\mathrm{A}_{i}, \mathrm{i}=0,7\right)$ by treating the ice concentrations from the intermediate ice chart as the dependent variable and the SSM/I attributes as the independent variables.

There are a range of potential attributes $\left(\mathrm{d}_{\mathrm{i}}, \mathrm{i}=0,7\right)$ that could be used in this algorithm. The attributes include partial concentrations from the NASA Team and Bootstrap algorithms and lower variance principal components of the data. No assumption is made about the physical meaning of these attributes. The justification for including lower variance principal components is work that suggests a relationship of these components to thin ice types that some conventional $\mathrm{SSM} / \mathrm{I}$ algorithms are poor at detecting [3,4,5]. Using the equations that specify the first five principal components of the SSM/I data from the entire Arctic generated on 9 December, 1998, and multiplying these by controlled brightness temperatures of known surface types confirms that this is the case (Figure 3 ). The $3^{\text {rd }}$ to $5^{\text {th }}$ components all show a sensitivity to new ice that is not apparent in the first two components.

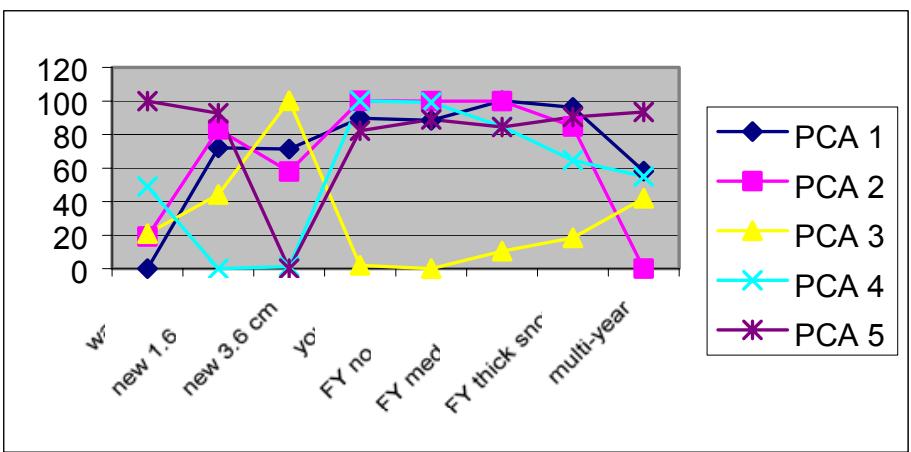

Figure 3. Normalized principal components of data from controlled observations, where the eigenvectors are generated using principal components from the entire Arctic on 9 December, 1998. The observations are derived from [4], [5] and [6].

\section{RESULTS}

Figure 4 shows the results of applying this algorithm to data from the Barents Sea in December, 1998.

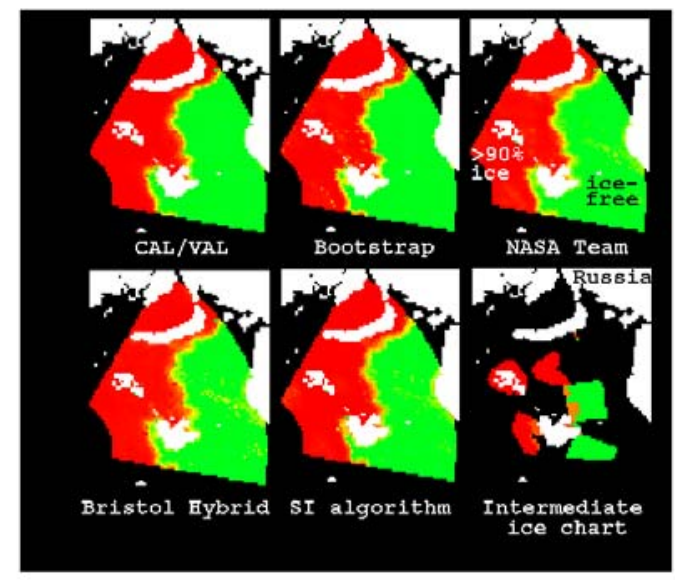

Figure 4. Kesuls ur apprying uIe si algoriunn, anlu other algorithms, to data from the Barents Sea, 7 December 1998. The intermediate ice chart (labeled "partial" ice chart), on which the SI algorithm is based, is shown for comparison (lower right).

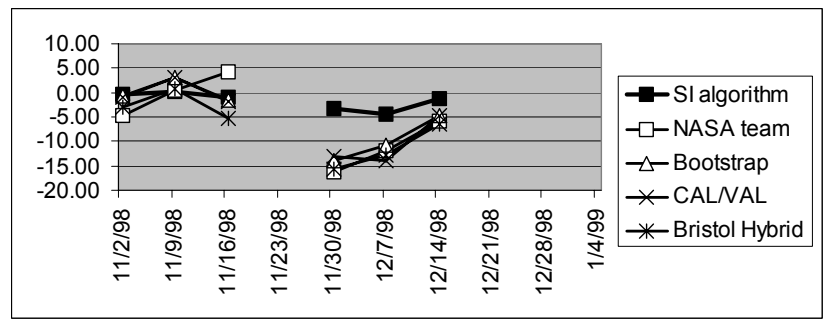


Figure 5. Mean difference (\% ice cover) between ice concentrations measured by algorithms and ice concentrations from intermediate ice charts, measured as a function of date for the Barents Sea.

Figures 5 and 6 show statistics measuring the behavior of the algorithm as a function of date through November and December 1998 in the Barents Sea. It can be seen that the SI algorithm achieves a significant improvement in terms of the general algorithm bias and the mean level of deviation.

These results are interesting, in terms of demonstrating a new method of evaluating SSM/I algorithms and by showing the level of improvement that can be achieved by tuning the SI algorithm to the ice chart. The results do not, however, provide an indication of the overall level of accuracy achieved by the SI algorithm, as the ice charts themselves contain errors. The SI algorithm can only be as good in quality as the ice chart itself, so if the ice analysis procedure contains errors, then these will be inherited by the algorithm. Nevertheless, as these intermediate ice charts are based on analysis of high and moderate resolution satellite data by an analyst who has access to climatology data, weather predictions, forecast model output and the previous weeks' ice chart, it is expected that the ice chart will represent the best synthesis of information available for most polar regions,

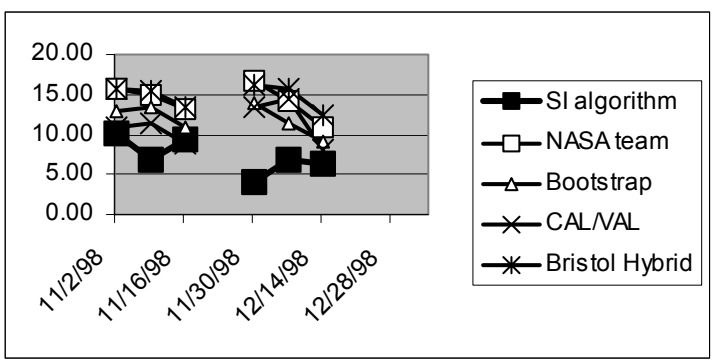

Figure 6 . Mean absolute difference ( $\%$ ice cover) between ice concentrations measured by algorithms and ice concentrations from intermediate ice charts, measured as a function of date for the Barents Sea.

\section{CONCLUSIONS AND RECOMMENDATIONS}

This study has shown how high resolution satellite data can be used to constrain analyses of lower resolution data in an operational environment. The SI is suitable for operational use as it provides very little impact on the analyst in terms of their time, yet has demonstrated an ability to significantly reduce the discrepancy between the information derived from $\mathrm{SSM} / \mathrm{I}$ and other sensors. The transition of this technique to an operational status is planned at NIC.

\section{ACKNOWLEDGEMENTS}

Robert Grumbine and Paul Chang of NOAA kindly provided SSM/I data in support of this study. The authors also thank Adnan Trakic for providing programming support.

\section{REFERENCES}

[1] J.R. Hollinger, R. Lo, G. Poe, R. Savage and J. Pierce, "Special Sensor Microwave / Imager Calibration/Validation", Final Report, Washington DC: Naval Research Laboratory, pp. 10-1 to $10-20,1991$.

[2] D. Cavalieri, P. Gloersen, P. and W.J. Campbell, "Determination of sea-ice parameters with the NIMBUS 7 SMMR", Jnl. Geophys. Res., vol. 89, no. D4, pp. 5355-5369, 1984.

[3] K.C. Partington, "Evaluation of Special Sensor Microwave Imager sea-ice data", this proceedings.

[4] T.C Grenfell, "Surface microwave passive microwave observations of sea-ice in the Bering and Greenland seas", IEEE Trans. Geosci. Rem. Sens., vol. GE-24, no. 3, pp. 378382, 1986.

[5] M. Wensnehan, G.A. Maykut, T.C. Grenfell and D.P. Winebrenner, Passive microwave remote sensing of thin sea ice using Principal Component Analysis, J. Geophys. Res., vol. 98, no. C7, pp. 12,453-12,468, 1993. 